\title{
Short communication: \\ Effects of the various source areas of Indonesian bay leaves (Syzygium polyanthum) on chemical content and antidiabetic activity
}

\author{
INDAH DWIATMI DEWIJANTI ${ }^{1,2, \bullet}$, WIBOWO MANGUNWARDOYO ${ }^{2, v \vee}$, ASTARI DWIRANTI ${ }^{2}$, \\ MUHAMMAD HANAFI ${ }^{1}$, NINA ARTANTI ${ }^{1}$ \\ ${ }^{1}$ Research Center for Chemistry, Indonesian Institute of Sciences. J1 Raya Puspiptek, Serpong, South Tangerang 15314, Banten, Indonesia. \\ Tel./fax.: +62-21-7560929, `email: dewiruslan@yahoo.com \\ ${ }^{2}$ Biology Graduate Program, Department of Biology, Faculty of Mathematics and Natural Sciences, Universitas Indonesia. J1. Lingkar UI, E Building \\ FMIPA-UI Campus, Depok 16242, West Java, Indonesia. Tel.: +62-21-7270163, Fax.: +62-21-78829010, "email: wibowo.mangun@ui.ac.id
}

Manuscript received: 2 December 2019. Revision accepted: 23 February 2020.

\begin{abstract}
Dewijanti ID, Mangunwardoyo W, Dwiranti A, Hanafi M, Artanti N. 2020. Short communication: Effects of the various source areas of Indonesian bay leaves (Syzygium polyanthum) on chemical content and antidiabetic activity. Biodiversitas 21: 11901195. Bay leaves (Syzygium polyanthum (Wight) Walp) are from an Indonesian plant species belonging to the Myrtaceae family. The Indonesian name for this plant is salam; it is found in Sumatra, Kalimantan, and the Java Islands. Its leaves are the part of the plant commonly used. Salam leaves are usually consumed by people as a food flavoring, but are also used as a traditional antidiabetic medicine. The purpose of this study was to discover the effects of salam leaves' origins on their chemical content and antidiabetic activity. For this reason, salam leaf samples were collected from three different provinces in Java (West Java, Central Java, and East Java). The samples were extracted by boiling in water. Phytochemical screening, chemical analysis using TLC, HPLC, LC-MSMS, and FTIR, and antidiabetic in vitro testing using alpha-glucosidase inhibition methods were conducted on the salam leaves' water extracts. The results showed that salam leaf extracts from all three provinces contained quercetin. However, the salam originating from East Java also contained coniferin, the salam from Central Java contained juncusol, and the salam from West Java contained retucine. The salam leaves originating from East Java showed the lowest antidiabetic activity, whereas salam leaf extract showed significantly higher antidiabetic activity. As conclusion, a plant's growth origin affects its chemical content and antidiabetic activity.
\end{abstract}

Keywords: Alpha-glucosidase inhibition method, phytochemical screening, salam, Syzygium polyanthum

\section{INTRODUCTION}

Syzygium species are widespread across various types of habitats. They number almost 1,200 and can be found in Africa, South Asia, Southeast Asia, Australia, Hawaii, New Caledonia, Malagasy, and New Zealand (Mudiana 2016) On the Java and Madura islands, 59 species were found (Hanan 1999), while in Kalimantan there are 165 species (Mudiana 2016). Although this genus has many species, little about it is known to the public. Usually its species are known when their fruit or leaves are consumed or used as raw material for medicine and industry (Mudiana 2016). One example is $S$. polyanthum.

Bay leaves (Syzygium polyanthum (Wight) Walp) are from an Indonesian plant species belonging to the Myrtaceae family. The Indonesian name for this plant is salam; it is found in Sumatra, Kalimantan, and Java. S. polyanthum trees are not widely cultivated on a large scale, instead usually planted in the yards of houses in Java to imply the philosophy of survival. This tree grows in West to East Java at an altitude of $5-1000 \mathrm{~m}$ asl (Indonesian Ministry of Health 1980; Harismah and Chusniatun 2017). Indonesian bay leaves, better known as salam, have other local names, such as gowok (Sundanese), kastolam (Kangean, Sumenep), and manting (Javanese) (Harismah and Chusniatun 2017). Its wood can be used for building houses and furniture, and its skin is used to dye bamboo matting brown-red and to tan fishing nets. The bark and leaves are used for the treatment of diarrhea, while a mixture of bark, roots, and leaves are crushed to provide relief from itching. Roots and salam fruits can be eaten as an antidote for alcohol intoxication, while salam leaves, either dry or fresh, are used by the community as seasonings or food deodorizers (Hanan 1999; Hidayati et al. 2017; Ismail and Ahmad 2019). The leaves can also be used for skin whitening (Setyawati et al. 2018) and as traditional medicine for gastritis, hypertension, hyperuricemia, inflammatory skin diseases, diarrhea, and lowering cholesterol, as well as for uric acid levels and diabetes (Ramli et al. 2017; Ismail and Ahmad 2019).

Diabetes is a chronic metabolic disease caused by damage to the pancreas, partly or in whole, resulting in impaired insulin secretion causing an increase in blood sugar (hyperglycemia). Treatment requires antidiabetic therapy, either from natural or synthetic ingredients (Williamson et al. 1998; Hui et al. 2009).

Natural material from plants is a potential source of chemicals that generally have physiological and bioactive effects. There are two types of metabolisms in plants, primary and secondary. The primary metabolism produces 
compounds used in the biosynthetic process, while the secondary metabolism produces active compounds that can be used as raw materials for medicines. Among them are alkaloids, phenolics, glycosides, terpenoids, and steroids (Matsjeh 2004). The chemical content and extract activity in plants are influenced by the location of the plants and the extraction process, including the use of solvents (Artanti et al. 2014).

The purpose of this research was to determine and evaluate the effects of location on $S$. polyantum extracts from several provinces in Java on chemical content and antidiabetic activity. Salam leaves ( $S$. polyanthum (Wight) Walp) were obtained by purchase at the traditional markets of the cities of Surabaya, East Java, Jogjakarta, Central Java, and Bogor, West Java. Phytochemical screening, analysis using TLC, LC-MSMS and FTIR, and antidiabetic testing in vitro using alpha-glucosidase inhibition methods were applied.

\section{MATERIALS AND METHODS}

\section{Materials}

Salam leaves [S. polyanthum (Wight)Walp] were obtained from the traditional markets of three provinces on the island of Java (East Java, Central Java, and West Java), Indonesia. The leaves were washed and dried in an oven at $50{ }^{\circ} \mathrm{C}$, then chopped and sieved through a 20 mesh sieve to produce uniformly sized powder.

\section{Procedures}

\section{Water extraction}

To obtain a crude extract of salam leaves, 20 grams of dried powder was boiled in $200 \mathrm{~mL}$ of boiling water for minutes and then filtered so that residue and filtrate. The filtrate was then dried in an oven at $<50{ }^{\circ} \mathrm{C}$ to obtain dried extract to be analyzed.

\section{Antidiabetic assay.}

The antidiabetic activity was measured as the inhibitory activity for $\alpha$-glucosidase using the method reported by Kim (Kim et al. 2004) with minor modifications. pNitrophenyl- $\alpha$-D-glucopyranoside $(3 \mathrm{mM})$ was used as a substrate, and yeast $\alpha$-glucosidase $(0.065$ units $/ \mathrm{mL})$ was used as the enzyme. Screening of $\alpha$-glucosidase inhibitory activity was conducted at a sample concentration of 200 $\mu \mathrm{g} / \mathrm{mL}$. The inhibitory effect on $\alpha$-glucosidase activity was determined by measuring the amount of p-nitrophenol released at $400 \mathrm{~nm}$. All tests were run in duplicate.

\section{Phytochemical screening}

Qualitative analysis of alkaloids, flavonoids, tannins, terpenoids, steroids, and saponins was carried out using the methods described according to Materia Medika Indonesia
V (Indonesian Ministry of Health 1989; Lachumy et al. 2010).

Briefly, the contents of alkaloids, flavonoids, tannins, terpenoids, steroids, and saponins are determined by separating the reactions and then recording the color changes. Quantitative analysis with spectroscopy was utilized to determine the total phenolic content as the equivalent of phloroglucinol dihydrate using the FolinCiocalteu method (Singleton and Rossi 1965), as well as the total flavonoid content as the quercetin equivalent using the $\mathrm{AlCl}_{3}$ method (Sultana et al. 2009).

\section{FTIR analysis}

Fourier transform infrared analysis (FTIR) was conducted by means of IR instrument Prestige-21, Shimadzu, to discover the functional groups formed.

\section{LC-MSMS analysis}

LC-MSMS analysis was done with XEVO G2-XS QTof, UPLC Columns C18, HSS T3. LC conditions: Mobile phase: $\mathrm{A}=$ water $/ 0.1 \%$ formic acid, $\mathrm{B}=$ acetonitrile/ $0.1 \%$ formic acid. Gradient: Starts at $5 \%$, at 1 $\min 5 \% \mathrm{~B}$, at $8 \mathrm{~min} 40 \% \mathrm{~B}$, at $11 \mathrm{~min} 100 \%$, at $13 \mathrm{~min}$ $100 \%$, and at $16 \mathrm{~min} 5 \%$. Flow rate: $0.3 \mathrm{~mL} / \mathrm{min}$, column temperature $40^{\circ} \mathrm{C}$, sample temperature $20^{\circ} \mathrm{C}$. Injection volume: $1 \mu \mathrm{L}$. MS Conditions: Source: ESI. Ion mode: Positive. V convoltage: $30 \mathrm{~V}$.

\section{Data analysis}

All tests were replicated three times, and the results are stated as standard deviations (SD). The quantitative results obtained were analyzed descriptively. All measurements were done in triplicate.

\section{RESULTS AND DISCUSSION}

\section{Antidiabetic}

It was seen that the antidiabetic activities of $S$. polyanthum extracts from various locations were not the same (Table 1). The salam extract from East Java (SEJ) showed only very low activity at a concentration of 100 ppm; hence, its testing was not continued. Extracts from Central Java (SCJ) and West Java (SWJ), however, showed similar significantly higher activity at the same concentration. Further analysis showed that SCJ had a slightly lower $\mathrm{IC}_{50}$ than SWJ, indicating that SCJ demonstrated slightly better antidiabetic activity than SWJ. This result is in accordance with previous studies conducted using another plant, pegagan (Centella asiatica (L.) Urb) (Artanti 2014) The same analysis conducted by Lelono in 2009 with simplicia from Sukabumi, West Java, showed $73 \mu \mathrm{g} \mathrm{mL} \mathrm{m}^{-1}$ activity. The extract content of a plant can be influenced by the plant's location of origin because of differences in atmosphere and environment, such as sunlight and rainfall (Indonesian Ministry of Health 1989). 
Table 1. $\alpha$-glucosidase inhibition of Syzygium polyanthum water extracts from various growth locations

\begin{tabular}{lccc}
\hline Samples & East Java (SEJ) & Central Java (SCJ) & West Java (SWJ) \\
\hline$\%$ inhibition at $100 \mathrm{ppm}$ & $10.38 \pm 0.85$ & $63.53 \pm 0.78$ & $63.20 \pm 0.90$ \\
$\mathrm{IC}_{50}$ & nd & $51.10 \pm 4.27$ & $65.44 \pm 5.32$ \\
\hline Note: nd=not determined & & &
\end{tabular}

Note: nd=not determined

Table 2. Phytochemical test of Syzygium polyanthum water extracts from various growth locations

\begin{tabular}{lcccl}
\hline \multirow{2}{*}{ Phytochemical test } & \multicolumn{3}{c}{ Sample } & \multirow{2}{*}{ Result } \\
\cline { 2 - 5 } & East Java (SEJ) & Central Java (SCJ) & West Java (SWJ) & Orange yellow \\
Flavonoids & + & ++ & ++ & White sediment \\
Alkaloids & ++ & ++ & ++ & Precipitation of brown orange \\
Meyer & ++ & +++ & + & Stabilized foam for minutes \\
Bouchardat & ++ & ++ & + & Green violet \\
Saponins & ++ & + & - & \\
Tannins & - & - & ++
\end{tabular}

Note: -: shows the absence of phytochemicals; +: shows the presence of phytochemicals; ++: shows the presence of abundant phytochemicals; and +++: shows the presence of highly abundant phytochemicals

Table 3. Total phenolic and total flavonoid contents of Syzygium polyanthum water extracts from various growth locations

\begin{tabular}{lccc}
\hline Samples & East Java (SEJ) & Central Java (SCJ) & West Java (SWJ) \\
\hline Total phenolic contents (ug GAE/mg extract) & $23.87 \pm 1.99$ & $106.80 \pm 5.63$ & $58.97 \pm 0.92$ \\
Total flavonoid contents (ug QE/mg extract) & $20.80 \pm 2.36$ & $52.05 \pm 6.25$ & $33.90 \pm 3.61$ \\
\hline
\end{tabular}

Note: GA: Gallic acid; QE: Quercetin

\section{Phytochemical screening}

Table 2 shows the qualitative phytochemical screening of $S$. polyanthum extracts from various growth locations. The results show that flavonoids, alkaloids, saponins, and tannins were detected in extracts from all locations and that terpenoids were undetected. Flavonoid content in SEJ was lower than in SCJ and SWJ. Flavonoids are natural organic compounds found in most plants, vegetables, and fruits that have a variety of biochemical benefits and antioxidant effects (Miranda 2012).

Alkaloid analysis from the three locations done by the Meyer method gave the same results, but with the Bouchardat method, the highest alkaloid content was from SCJ and the lowest was from SEJ. Alkaloids are chemical compounds produced by secondary metabolites that are formed based on the principle of formation of a mixture (Darwis 2001). Alkaloids can be found in various parts of the plant, functioning as a poison that can protect it from insects and herbivores, as growth regulating factors, and as storage compounds that can supply nitrogen and other elements needed by plants (Wink 2008). Alkaloids can be determined qualitatively by testing using a Mayer reagent containing the heavy metals potassium, mercury, and iodide, which react with nitrogen alkaloids to form sediment, whereas the Bouchardart reagent consists of iodine and potassium iodide, which react with alkaloids to form complex colored salts that are difficult to dissolve in water (Roth and Blascheke 1988). Saponis content in extracts from SEJ, SCJ, and SWJ were qualitatively similar. Saponins are also referred to as natural detergents; the name is from the Latin "sapo," which means soap, because of the dominant characteristic of soap-like saponins (Calabria 2008; Hawley and Hawley 2004)foam (Baud et al. 2014). Tannin content was qualitatively highest in the SEJ extracts; lower tannin content was detected in the SCJ and SWJ extracts. Tannins are chemically astringent and are of two types, hydrolyzed and condensed (Harborne 1998). Both have astringent, antiinflammatory, antimicrobial, antidiarrheal, and antioxidant properties. Condensed tannins have another characteristic, hypocholesterolemia (Mills and Bone 2000).

The quantitative analysis results of the total phenol content and total flavonoids in extracts from various locations can be seen in Table 3. The results, from lowest to highest in terms of total phenolic, are $\mathrm{SEJ}<\mathrm{SWJ}<\mathrm{SCJ}$. These results support the antidiabetic activity results of these extracts (Table1). SCJ demonstrated the highest aglucosidase inhibitory activity and the highest total phenol and total flavonoid content. Flavonoid is a secondary metabolite that shows various pharmacological properties and is bioactive as a drug. (Nuari et al. 2017). Many flavonoids have been reported to play an important role in the prevention of diabetes and its complications. Several studies using different experimental models have been conducted to show the hypoglycemic effect of flavonoids. The results have shown that plants containing flavonoids have beneficial effects in fighting diabetes mellitus, through the ability to both reduce glucose absorption and increase glucose tolerance (Brahmachari 2011). 


\section{Thin Layer Chromatography (TLC)}

Thin-layer chromatograms of salam water extracts from various locations were developed in chlorofom/acetone and chloroform/methanol eluents. Thin layer chromatography (TLC) was carried out to determine the chromatogram profile of the compounds present in SEJ, SCJ, and SWJ extracts. Chloroform: acetone (3:2) and Chloroform: methanol (4:1) were used as the mobile phase, and the chromatogram pattern is seen at a wavelength of $254 \mathrm{~nm}$. The chromatogram patterns of the three extracts were seen in the two types of eluents used. At the same concentration, SCJ showed a higher intensity than SEJ and SWJ, leading to the prediction that there were several compounds in SCJ that caused the highest antidiabetic activity (Figure 1).

\section{Fourier Transform Infrared Analysis (FTIR)}

The spectra of FTIR analysis are shown in Figure 2. This analysis was carried out to determine the existence of functional groups that exist in the extracts of several locations (SEJ, SCJ, SWJ), with quercetin and quercitrin as guide compounds. Those two compounds were used since they are flavonoids commonly present in many plants and because the results for $S$. polyanthum in this study showed the presence of flavonoids in the extracts (Tables 2 and 3). The existence of $-\mathrm{OH}$ bonds $\mathrm{C}-\mathrm{C}$, aromatic $\mathrm{C}-\mathrm{O}$ bonds, aromatic $\mathrm{C}-\mathrm{H}$ and others is shown in Table 4.
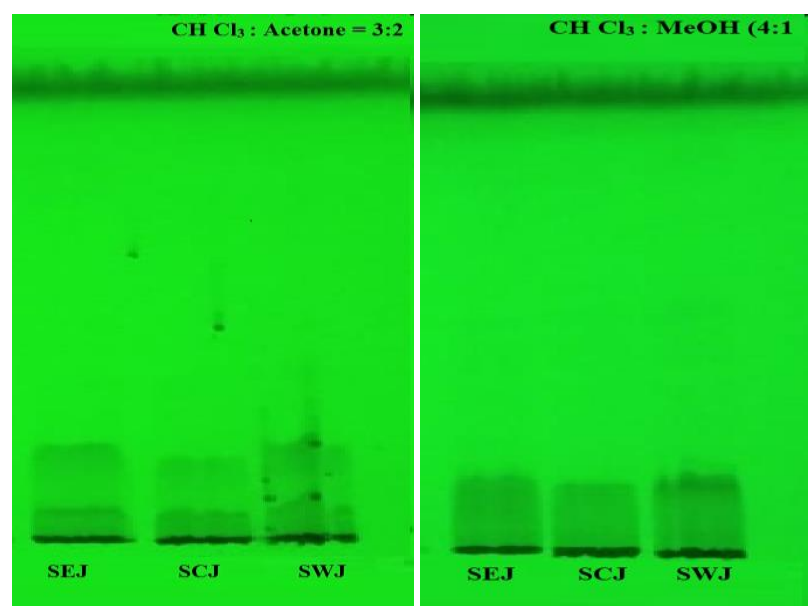

Figure 1. A. $\mathrm{CH} \mathrm{Cl}_{3}$ : Acetone $(3: 2 ; \mathrm{v} / \mathrm{v})$ eluent, B. $\mathrm{CH} \mathrm{Cl}$ : $\mathrm{MeOH}(4: 1 ; \mathrm{v} / \mathrm{v})$ eluent

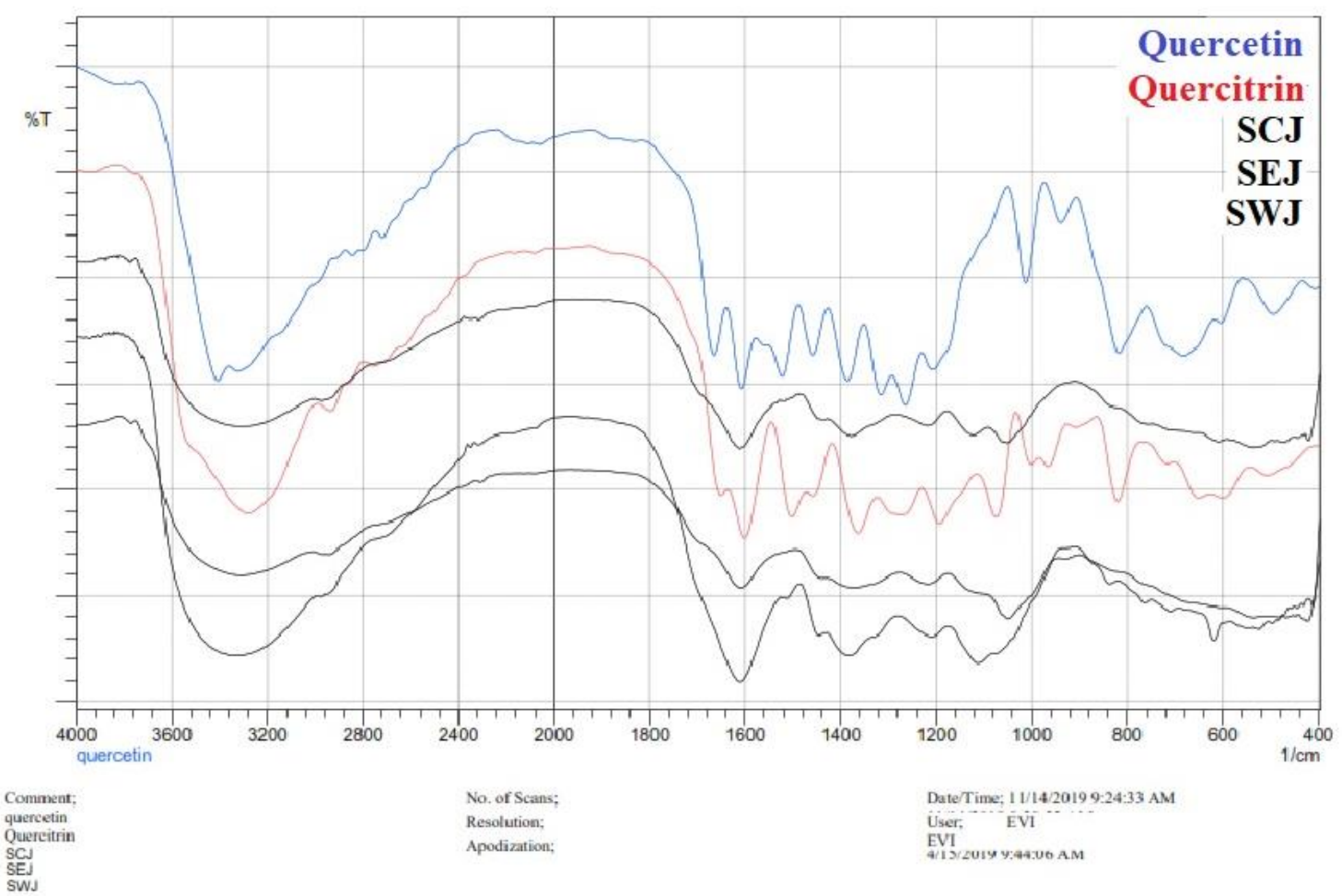

Figure 2. Fourier transform infrared (FTIR) analysis of Syzygium polyanthum water extracts from various growth locations

Table 4. Specific bands of IR spectra of chemical compounds examined from Syzygium polyanthum water extracts from various growth locations

\begin{tabular}{lllccc}
\hline Functional groups & Quercetin & Quercitrin & East Java (SEJ) & Central Java (SCJ) & West Java (SWJ) \\
\hline OH stretch & 3408.22 & 3284.77 & 3340.71 & 3271.27 & 3307.92 \\
CH & 2717.7 & 2945.3 & 2980.02 & 2972.31 & 2939.52 \\
C=O & 1608.63 & 1654.92 & 1610.56 & 1608.63 & 1610.56 \\
\hline
\end{tabular}


Table 4. Liquid chromatography tandem-mass spectrometry (LC-MS/MS) of chemical compounds examined from Syzygium polyanthum water extracts from various growth locations

\begin{tabular}{|c|c|c|c|c|c|c|}
\hline \multirow{2}{*}{$\begin{array}{l}\text { Location } \\
\text { Component name }\end{array}$} & \multicolumn{2}{|c|}{ East Java (SEJ) } & \multicolumn{2}{|c|}{ Central Java (SCJ) } & \multicolumn{2}{|c|}{ West Java (SWJ) } \\
\hline & Quercetin & Coniferin & Quercetin & Juncusol & Quercetin & Retusine \\
\hline Observed m/z & 303.0609 & 365.1137 & 303.0606 & 289.1187 & 303.0610 & 381.0872 \\
\hline Neutral mass (Da) & 302.0465 & 342.13147 & 302.04265 & 266.13068 & 302.04265 & 358.10525 \\
\hline Adducts & $+\mathrm{H}$ & $+\mathrm{Na}$ & $+\mathrm{H}$ & $+\mathrm{Na}$ & $+\mathrm{H}$ & $+\mathrm{Na}$ \\
\hline Observed RT (min) & 5.48 & 1.16 & 5.48 & 6.38 & 5.48 & 1.17 \\
\hline Formula & $\mathrm{C}_{15} \mathrm{H}_{10} \mathrm{O}_{7}$ & $\mathrm{C}_{16} \mathrm{H}_{22} \mathrm{O}_{8}$ & $\mathrm{C}_{15} \mathrm{H}_{10} \mathrm{O}_{7}$ & $\mathrm{C}_{18} \mathrm{H}_{18} \mathrm{O}_{2}$ & $\mathrm{C}_{15} \mathrm{H}_{10} \mathrm{O}_{7}$ & $\mathrm{C}_{19} \mathrm{H}_{18} \mathrm{O}_{7}$ \\
\hline
\end{tabular}<smiles></smiles><smiles>COc1cc(/C=C/CO)ccc1O[C@@H]1O[C@H](CO)[C@@H](O)[C@H](O)[C@H]1O</smiles><smiles>C=Cc1c(C)c(O)cc2c1-c1ccc(O)c(C)c1CC2</smiles><smiles>[R14]CCCCCCCC</smiles>

Figure 3. Chemical structure of quercetin, coniferin, juncusol, and retusine

\section{Liquid chromatography tandem mass spectrometry (LC-MS/MS)}

LC-MS/MS is a high-resolution analysis technique that can be used in quantitative and structural analysis, providing a very useful approach in determining the profile of a metabolite (Theodoridis et al. 2008). The results of LC-MS/MS analysis of $S$. polyanthum extracts from various areas can be seen in Table 4 and Figure 3. It was predicted that the SEJ extract contains quercetin and coniferin compounds, the SCJ extract contains quercetin and juncusol compounds, and the SWJ extract, in addition to quercetin, contains retucine. Although all locations were predicted to contain quercetin compounds, which are known to have antidiabetic activity, the level of activity of extracts from each region is different because of the interaction of quersetin compounds with other compounds that can be antagonistic-decreasing activity-or synergistic - strengthening activity (Syahrir 2016).

It can be concluded that salam leaves derived from Central Java possessed strong anti-diabetic activity compared to the salam leaves from the two other locations.

\section{ACKNOWLEDGEMENTS}

This study was funded by Indonesian Ministry of Research, Technology, and Higher Education and Research Center for Chemistry, Indonesian Institute of Sciences. Authors are thankful to Dr. Jamilah Abbas, Lia Meilawati, Lala Filaila and Tria for their support and collaboration.

\section{REFERENCES}

Artanti N, Dewi RT, Maryani F. 2014; Pengaruh lokasi dan pelarut pengekstraksi terhadap kandungan fitokimia dan aktivitas antioksidan ekstrak pegagan (Centella asiatica L. Urb). Jurnal Kimia Terapan Indonesia 16 (2) 88-92. [Indonesian]

Baud GS, Sangi MS, Koleangan HSJ. 2014. Analisis senyawa metabolit sekunder dan uji toksisitas ekstrak etanol batang tanaman patah tulang (Euphorbia tirucalli L.). dengan metode brine shrimp lethality test (BSLT). Jurnal Ilmiah Sains 14 (2): 106-112. [Indonesian]

Brahmachari G. 2011. Bio-flavonoids with promising antidiabetic potentials: A critical survey. Res Signpost 187-212.

Calabria LM. 2008. The isolation and characterization of triterpene saponins from silphium and the shemosystematic and biological 
significance of saponins in the asteraceae. School of Biological Sciences, University Texas at Austin, Austin, TX.

Darwis D. 2001. Teknik Isolasidan Karakterisasi Senyawa Metabolit Sekunder, Workshop Peningkatan Sumber Daya Manusia untuk Pemanfaatan Suber daya alam hayati dan rekayasa bioteknolog. FMIPA Universitas Andalas, Padang. [Indonesian]

Hanan A. 1999. Etnobotani salam di daerah Cirebon: Pemanfaatannya sebagai bahan penyedap alami. J Indonesian Med Plants 5 (3): 7-9. [Indonesian]

Harborne JB. 1998. Phytochemical Methods: A Guide to Modern Techniques of Plant Analysis. 3rd ed. Springer Science+Business Media B.V., New York.

Harismah K, Chusniatun. 2017. Utilization of bay leaves (Eugenia polyantha) as herbal medicine and food flavoring herbs. Warta LPM 19 (2): 110-118. [Indonesian]

Hawley TS, Hawley RG. 2004. Flow cytometry protocols. Humana Press. New Jersey.

Hidayati MD, Ersam T, Shimizu K, Fatmawati S. 2017 Antioxidan activity of Syzygium polyanthum extracts. Indonesian J Chem 17 (1): 49-53.

Hui H, George T, Vay LWG. 2009. Hypoglycemic herbs and their action mechanisms. Rev Chin Med 4: 11.

Indonesian Ministry of Health 1989. Materia Medika Indonesia, V Jakarta. Directorate General of the National Agency for Drug and Food Control [Indonesian]

Indonesian Ministry of Health. 1980. Materia Medica IV Director General of the National Agency of Drug and Food Control of Republic of Indonesia [Indonesian]

Ismail A, Ahmad WAN. 2019. Syzygium polyanthum (Wight) Walp: A potential phytomedicine. Pharmacognosy J 11 (2): 429-438.

Kim YM, Wang MH, Rhee, HI. 2004. A Novel Alpha-glucosidase Inhibitor from Pine Bark. Carbohydr Res 339 (3): 715-717.

Lachumy SJT, Sasidharan S, Sumathy V, Zuraini Z. 2010. Pharmacological activity, phytochemical analysis and toxicity of methanol extract of Etlingera elatior (torch ginger) flowers. Asian Pac J Trop Med (2010)769-774.

Matsjeh S. 2004. Sintesa flavonoid: Potensi metabolit sekunder aromatik dari sumber daya alam nabati Indonesia. Universitas Gadjah Mada, Yogyakarta. [Indonesian]
Mills S, Bone K. 2000. Principles and Practice of Phytotherapy Modern Herbal Medicine. Churchill Livingstone Publisher 569-580.

Miranda C, Maier CS, Stevens JF. 2012. Flavonoid. John Wiley \& Sons, Ltd., New York. DOI: 10.1002/9780470015902.a0003068.pub2

Mudiana D. 2016. Syzygium diversity in Gunung Baung, East Java, Indonesia. Biodiversitas 17: 733-740.

Nuari S, Syariful A, Akhmad K. 2017. Isolation and identification of flavonoid compounds from ethanol extract of red dragon fruits (Hylocereus polyrhizus (F.A.C.Weber) Briton \& Rose. Galenika J Pharm 2 (2): 118-125. [Indonesian]

Ramli S, Radu S, Rukayadi Y. 2017. Antibacterial activity of ethanolic extract of Syzygium polyanthum L. (Salam) leaves against foodborne pathogens and application as food sanitizer. BioMed Res Intl 2017: 9024246. DOI: $10.1155 / 2017 / 9024246$

Roth HJ, Blaschke G. 1988, Analisis Farmasi. Gajah Mada University Press, Yogyakarta. [Indonesian]

Setyawati A, Kae H, Kosei Y, Hiroyuki H, Tohru M, Irmanida B, Rudi H, Hiroshi H, Mitsuyuki H. 2018. Melanogenesis inhibitory activity of components from Salam leaf (Syzygium polyanthum) extract. J Nat Med 72; 474-480. DOI: 10.1007/s11418-018-1171-4.

Singleton VL, Rossi JA. 1965. Colorimetry of total phenolics with phosphomolybdic-phosphotungstic acid reagents. Am J Enol Vitic 16: 144-158.

Sultana B, Anwar F, Ashraf M. 2009 Effect of extraction solvent/technique on the antioxidant activity of selected medicinal plant extracts. Molecules 14: 2167-2180.

Syahrir NHA, Afendi FM, Susetyo B. 2016. Efek sinergis bahan aktif tanaman obat berbasiskan jejaring dengan protein target. Jurnal Jamu Indonesia 1 (1): 35-46. [Indonesian]

Theodoridis G, Gika HG, Wilson ID. 2008. LC-MS-based methodology for global metabolite profiling in etabonomics/metabolomics. TrAC Trends Anal Chem 27 (3): 251-260.

Williamson EM, Okpoko DT, Evans FJ. 1998. Selection, Preparation and Pharmacology: Evaluation of Plant Material. Pharmacological Method in Phytotherapy Research. John Willey \& Sons, Chichester.

Wink M. 2008. Ecological roles of alkaloids. Wink M (ed). Modern Alkaloids, Structure, Isolation Synthesis and Biology. Wiley-VCH Verlag GmbH \& Co. KgaA, Germany. 